\title{
Thinking on Transformation Development of Higher Education in Our Country under New Normal
}

\author{
Dawei Guan \\ Huanghe Science and Technology College \\ Zhengzhou, China
}

\begin{abstract}
New Normal" is the keyword of new ruling idea of the central government. The economic development of our country enters the New Normal. The development of higher education shall timely adapt to new changes. The fading of "Demographic Dividend" of our country means that the largescale expanding stage of higher education in our country has come to an end. It is the only way to respond to the New Normal through promoting transformation development of higher education. At present, the comprehensive reform in the field of higher education has roundly begun. There are all kinds of tasks. It is necessary to seize the key task and break through key points under the circumstances. The author thinks that firstly we should see current situation and problems existing in higher education of our country clearly, and then promote transformation development of higher education on the basis of problems and put forward countermeasures and suggestions of transformation development.
\end{abstract}

Keywords-new normal; current situation of higher education; existing problems; countermeasure

\section{Problems Existing IN Higher EdUCATION OF OUR COUNTRY}

In the process of rapid development, higher education of our country appears many problems. It is impossible to name them one by one. This article only analyzes some problems.

\section{A. Problems of Opportunity Fair of Higher Education}

Although the enrollment expansion policy in universities makes increasing number of people have the opportunity to receive higher education, but is cannot be denied that the unfairness of educational opportunities still exists. At the present stage, the educational unfairness in our country mainly shows: On one hand, the distribution of educational resources is imbalanced. Great differences exist between eastern region and western region, central city and remote areas on educational input such as manpower, material resources and financial resources. Although in the same city, the distribution of high quality educational resources is imbalanced. The enrollment marks of the same university in different provinces and cities are greatly different; on the other hand, the distribution of higher education opportunity of China in all levels of society is seriously imbalanced. At present, social status and economic condition owned by different status are different to a large extent. Children of cadres, intellectuals and high-income families have more opportunities to receive higher education. People with lower social status have stronger requirements for realization of educational fairness. At the present stage, higher education equality of our country has become a prominent social issue.

\section{B. Problems of Enrollment Scale and Quality of Talent Training}

The popular education implemented in our country meets requirements of industries for various talents to some extent, but problems exposed are also obvious. On one hand, the number of students increases rapidly; on the other hand, available resources in universities are limited. Without enough hardware facilities, most students cannot fully practice their operational ability. Lacking qualified teachers, many professional courses cannot be on the rails. The teaching level of teachers is not high, so that it is impossible for students to receive comprehensive professional knowledge. After graduation, they cannot timely adjust and change according to social demands and cannot meet the requirements of social development. It further triggers the problem that the quality of talent training reduces.

\section{Problem that Educational Concept in Universities Departs from Spirit of University Education}

Tao Xingzhi, the most famous educator of our country, once put forward, "The foundation of education is to educate people. The primary task of educating people is to shape virtues". Therefore, "student-oriented" cultivation of talents is the foundation of all levels of universities to settle down and get on with their pursuit. However, the practical condition is that in order to pursue the biggest economic benefits, many universities continuously expand and compare unrealistically. On school-running purpose, they use gaudy political achievements to replace talent training. On school-running value, they use bureaucratic standard and executive standard to replace academic standard and educational standard, think little of essential property of cultivation-orientation of university education and depart from independent university spirit.

\section{Specialty Structure and Curriculum Provision Cannot Meet Requirements of Market and Society}

The most prominent characteristic of traditional university education is to start with traditional "discipline-based" mode and consider course development with complete discipline system as the starting point, pay attention to integral, 
systematic and rigorous theoretical knowledge, lack mastering of social needs. The quality of talents mainly depends on teachers and conditions of running schools. Therefore, on curriculum provision, it leads to more theory teaching and less practice teaching; more required courses and less elective course. The major setup also sticks to convention, lacks innovation and cannot adapt to development of the society.

The major setup in some universities is seriously backward. With antiquated teaching methods, they cannot make proper adjustments according to social development. Professional education seriously departs from social needs. Besides, universities enlarge enrollment scale through fined specialty, which reduce learning stress of students and go against training of students' innovation ability.

\section{E. Employment Difficulty of College Students}

Employment of college students is the strategic core issue in problem of employment of our country. Employment difficulty of college students has become a special problem in a series of employment problems of our country at present. Nowadays, students cultivated by universities lack practical skill and ability. A large number of theoretical courses make students unqualified on major orientation. Besides, from the perspective of employment status, it is not the supply of number of college students that exceeds demand, but the supply of structure of college students that exceeds demand. It is because the cultivation direction and contents that shall be learnt by college students depart from actual demands of the society; the channel of employment is not smooth; and employment systems in enterprises and public institutions are unreasonable.

\section{IDEAS FOR TRANSFORMATION DEVELOPMENT OF HIGHER EDUCATION IN OUR COUNTRY}

In face of these problems existing in higher education of our country, advancing higher education reform is the only way. It is still difficult to truly cultivate applied talents that can adapt to local economy and social development.

\section{A. Change from Denotative Development to Connotative Development}

Since enrollment expansion of universities in 1999, higher education in our country has mainly adopted denotative development and spanned from elite higher education to mass higher education in a very short period of time. However, the development way that pays attention to scale and speed is not a normal development. In addition, it has showed the trend of declination in recent years. Without timely adjustment, it will directly influence the development of higher education of our country in the future.

The fading of "Demographic Dividend" means the largescale expansion period of higher education in our country is coming to an end. The growing rate of higher education scale reduces. The retardation of speed will become New Normal. It has become New Normal that candidates "vote with their feet". It means that universities will face increasingly fierce competition of student source from our country as well as foreign countries. It is no longer competitive to rely on expanding scale blindly. Therefore, the most fundamental way to meet New Normal is to advance the change of development way of higher education in our country-changing from the past denotative development to connotative development.

The report of the 18th National Congress of the Communist Party of China clearly points out that it is necessary to "promote connotative development of higher education". It indicates that higher education of our country has gradually entered the stage of connotative transformation development with improvement of quality of core mission. The theoretical cycle and practice circle of higher education shall unify and deepen understanding, improve quality of higher education in theoretical research and practical exploration and explore a variety of specific strategies of connotative development road; it is necessary to pay more attention to rules of educational development, seriously and meticulously implement in the field of higher education, take moral education and personnel cultivation as basic tasks, provide environment and opportunities for each educator and educatee to use "slow work to yield fine products", optimize higher education construction and structure of talent cultivation and firmly promote connotative development of higher education.

\section{B. Change from One-way Management to Diversified Management}

Since the reform and opening up, because gaps exist between our country and western developed countries on comprehensive national strength, our country adopts the strategy of pursuing them all the time, no matter in economic field or educational and cultural fields. In various stages of pursuing, the powerful "visible hand" of the government always serves as strong backing. However, for development of higher education, the interference of government is a doubleedged sword. On one hand, under powerful interference and strong support of the government, higher education of our country gradually walks on the development road different from western higher education. Since the reform and opening up, the development of higher education in our country duplicates "Economic Miracle". The increase of various data and indicators is awe-inspiring. On the other hand, the government excessively and concretely controls higher education. It weakens the autonomy of universities in running schools and lowers the spiritual character of universities. It is because for a long time, our country adopts superincumbent management system of higher education and unidirectional management methods and means. Under this governance pattern, although higher education in our country gets a large number of resource investment required by rapid development, it is difficult to eliminate administration of universities. The “Asking of Qian Xuesen" related to cultivation of excellent talents remains to be solved. It is also the key that hinders our country to move from big country of higher education towards great power of higher education.

Therefore, in essence, the governance pattern of higher education is a transitional governance pattern adopted in special period. The strategy of pursuing other countries and it complement each other. However, after these years of pursuing and rapid development, the higher education of our country 
has ranked number one in the world on scale and become veritable great power of higher education. If we say that in the development period of pursuing other countries, strengthening the involvement of government in higher education is the last resort, in the new development stage, we have enough selfconfidence to carry out construction of higher education more leisurely. Besides, from the perspective of external conditions, the relationship between higher education of our country and the outside world also strengthens continuously. The higher education system becomes more diversified and complicated. It plays a greater and greater role and becomes veritable "center of the society". Under the circumstances, it is difficult to continue to rely on simple one-way management way to manage higher education, because no government can control each detail of higher education development. Therefore, both development requirements of higher education in our country and changes faced by external environment of higher education have urgent requirements for transformation of governance pattern of higher education.

\section{Change Thinking on Management Mode}

1) Adjust training objectives of higher education and pay attention to comprehensive quality education: The important teaching objectives of university education are knowledge accumulation, ability training and development of individual quality of college students. The purpose of acquiring knowledge is the basis. The development of ability and individual quality is the ultimate goal. Rogers, the humanistic psychologist, puts forward "human-centered" educational view and opposes any education that puts human in secondary position. Therefore, higher education shall insist on "studentbased" education, teach students in accordance of their aptitude and cultivate comprehensive talents that meet social needs.

2) Pay attention to teaching reform and actively adjust specialty structure and curriculum provision: Universities shall open corresponding courses according to objective of talents training and implement education training mode of "basic quality + professional ability" on curriculum provision. The course contents need to accurately reflect main knowledge of discipline and trend of era development. On the basis of building integrated curriculum system, deepen reform of teaching method and change from closed classroom teaching to multidimensional "big class" teaching, teaching students in accordance of their aptitude, stimulate students' enthusiasm in learning and thirst for knowledge, exert students' initiative in learning and train students' ability in finding, analyzing and solving problems.

3) Strengthen training of college students' occupational qualities and occupational guidance and encourage students to become self-employed: Einstein once said, "It is insufficient to use professional knowledge to educate people. With professional education, people can become useful machine instead of people with harmonious development". Except for professional knowledge, harmonious person need to have comprehensive occupational qualities. In order to reach this purpose, we shall achieve the following points: Firstly, in revision of personnel cultivating program, bring cultivation of professional quality of college students into systems engineering of talents training and run it through the whole process of university education. Secondly, in framework of curriculum system of different specialties, attach importance to courses of College Student Employment and Entrepreneurship Guidance and College Student Professional Quality Development. Thirdly, college students shall improve professional quality through self-cultivation. Finally, make use of social resources such as cooperation between school and enterprise, entrepreneur lecture and social training to improve professional quality of college students.

\section{Change Thinking on Ideology}

1) Higher education develops towards lifelong education: The coming of information technology era accelerates update of human knowledge, which puts forward new requirements for talents training. In the past, scientific and cultural knowledge acquired by talents of higher education in school can make them stay at the forefront of the times for a long time after employment. However, in network information age, it requires high-end technical talents to continuously learn the latest knowledge technology after graduation to adapt to the era with rapid development and society with fierce competition. Therefore, continuing education concept and life-long education theory are accepted by more and more people. Under this background, the college entrance examination is no longer the only opportunity acquired by students to receive higher education. Higher vocational education, adult higher education and self taught examination education provide more choices for continuing education and life-long education of people, form three-dimensional and lifelong education system with mutual integration and coherence of academic education and non-academic education.

2) School-running effects change from extensive type to optimization: With the development of time and social progress, our country has increasingly high requirements for quality of talents training of higher education. It is the problem that must be faced by higher education and inevitable choice for higher education to survive and develop to unceasingly meet high level academic requirements of social development. In order to further improve the quality of teaching and optimize teaching effects, the Ministry of Education issues Some Opinions on Further Deepening Undergraduate Teaching Reform and Comprehensively Improving Quality of Teaching. According to the instruction, universities make efforts to start with increasing input of teaching, strengthening teaching team, optimizing teaching contents, reforming teaching methods, innovating teaching means, reinforcing discipline construction and intensifying scientific research management, improve quality of teaching, optimize teaching effects and cultivate all kinds of innovative talents for the development of our country. Therefore, the improvement of teaching quality will become the main task 
and strategic emphasis after leapfrog development of higher education.

3) Higher education develops toward combination involving production, teaching and research: The fundamental objective of higher education is to shape various applied technical talents for the development of times and social progress. Therefore, in order to guarantee talents can rapidly turn knowledge of their own into practical productive forces, it is the inevitable requirements for reform and development of higher education to closely cooperate with factories and mines, enterprises and scientific research institutions. Universities must walk on the road of industryuniversity-research cooperation. According to demands of the time of social development for talents training, universities need to adjust major setup, optimize curriculum system, and innovate in talents training mode and reform enrollment mode on the basis of realistic requirements. Only in this way can they cultivate talents that meet social needs and innovate in high level achievements in scientific research as well as serve the society directly.

4) Higher education turns into internationalization development: With increasingly obvious globalization tendency, our country also quickens the pace of international exchange and cooperation. There are more and more opportunities for international integration of education. In order to further improve quality of talent training and level to serve the society in higher education of our country, since the 1990s, higher education in our country has begun to actively participate in education service and competition within global range. The exchange and cooperation between domestic universities and foreign universities as well as scientific research institutions are increasingly extensive. Higher education presents obvious internationalization trend. Under the background of internationalization, the depth and range of opening to the outside world of higher education will be deeper and broader. It also makes talents cultivated by our country have international view and get more familiar with international rules, and then lay more solid foundation of talents for realization of Chinese Dream.

5) Traditional education means develop towards informatization: The coming of information network era makes education means of higher education increasingly develop toward informatization. Multimedia teaching and networking of campus have been popularized. Modern information technology greatly influences traditional higher education mode and sharply improves utilization efficiency of educational resources. Under the background of high degree informatization, students can choose schools and specialties suitable for themselves according to practical situation and freely select time and place for online learning. The implementation of online higher education of our country will be more helpful for development of students' individuality and creativity.

6) Develop towards universities of application-oriented type: Nowadays, with industry transformation and upgrading and economic globalization, it is the basic path for transformation development of local universities to strengthen research on applied science and technology. Schools must actively guide and intensify research on applied science and technology, establish good cooperation and service relationship with local place and enterprises, pay attention to transformation of scientific research achievement and technology application and improve the ability to serve local economic and social development. Set up incentive mechanism, support and encourage teachers to go to the society, actively integrate in local place and enterprises, and positively participate in government decision consulting and policy research and technological transformation of enterprises, technological innovation and technology promotion. Build applied scientific research platform to serve local economic and social development, construct research and development center of engineering technology with local characteristics, humanities and social science research center and policy advisory organs to provide consulting and reference for great decision of local governments, actively implement research and development of applied technology and social services.

\section{CONCLUSION}

The construction of higher education management system and transformation of governance patterns in our country under New Normal require scientific and reasonable top-level design, need to exert grass-roots vitality, produce benign interaction and improve governance ability through diversified system design with shared governance, to provide solid guarantee for substantial reform of higher education in our country. Nowadays, higher education in our country has entered New Normal. It is the key to test whether the great practice that our country changes from big country of higher education to great power of higher education can achieve success about how to adapt to New Normal and promoting double transition of higher education on development pattern and governance pattern.

\section{REFERENCES}

[1] Chen Shenhua, Wang Zhujing, Long Chengjian. Discussion on Total Quality Management of Higher Education [J], Journal of National Academy of Education Administration, the 3rd issue in 2010.

[2] Lin Lin. Research on Local Universities to Implement Total Quality Management [D], Bohai University, 2014.

[3] Li Hua. Discussion on Teaching Reform after Enrollment Expansion of Universities [J], Heilongjiang Researches on Higher Education, the 9th issue in 2005.

[4] Zhang Ying, Liu Chunyuan. Exploration on Application-oriented University to Implement "Excellent Program" [J], Work and Study Abroad (Employment Version), the 8th issue in 2011. 